\title{
THE INFLUENCE OF PERCEIVED QUALITY, BRAND IMAGE, AND EMOTIONAL VALUE TOWARDS PURCHASE INTENTION OF CONSINA BACKPACK
}

\author{
Basrah Saidani \\ Faculty of Economics Universitas Negeri Jakarta \\ e-mail: basrah@gmail.com \\ Muh. Sifaul Muztahid \\ Faculty of Economics Universitas Negeri Jakarta \\ e-mail: sipau188@gmail.com \\ Andrian Haro \\ Faculty of Economics Universitas Negeri Jakarta \\ e-mail: andrianharo@feunj.ac.id
}

\begin{abstract}
This study was conducted to determine the descriptive and empirical impact of perceived quality, brand image and emotional value toward purchase intention. The object of this research was respondents of backpack users in East Jakarta. Methods of data collection using survey methods. Data analysis using SPSS to process and analyze the research data. The results of descriptive test explained that perceived quality, brand image and emotional value of backpack Consina is good according most respondents answer, so they have quite high purchase intention. The hypothesis test shows, perceived quality has positive and significant effect on purchase intention, brand image has positive and significant effect on purchase intention, emotional value has positive and significant effect on purchase intention, perceived quality, brand image and emotional value have simultaneous effect on purchase intention.
\end{abstract}

Keywords: Perceived Quality, Brand Image, Emotional Value, Purchase Intention 


\section{PENDAHULUAN}

Beberapa tahun belakangan ini terus terjadi kenaikan permintaan pada pasar tas ransel di Indonesia. Permintaan tersebut di dorong dengan terus berkembangnya tren aktifitas outdoor di Indonesia seperti kegiatan pendakian gunung dan kegiatan traveling ala backpacker. Hal tersebut terlihat pada Gambar 1 yang menunjukkan terus meningkatnya tingkat pencarian pada kata kunci tas ransel melalui Google pada lima tahun terakhir.

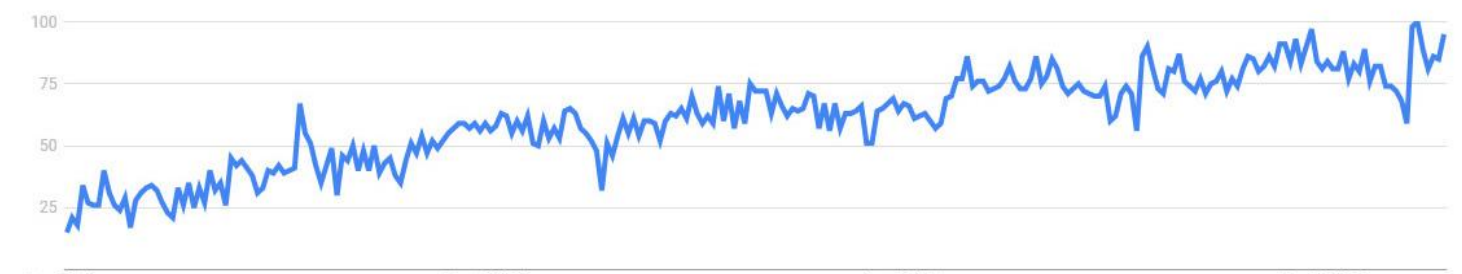

Gambar 1. Trend Pencarian Tas Ransel Tahun 2011-2016

Sumber : Google Trends (www.google.com/trends/)

Tas ransel yang beredar di Indonesia bukan hanya berasal dari merek-merek lokal, namun juga banyak yang berasal dari merek luar negeri. Hal tersebut terjadi karena pada era saat ini sedang terjadi arus globalisasi yang kuat. Arus globalisasi akan turut mempengaruhi kondisi dari suatu pasar, terutama pasar secara global.

Arus globalisasi membawa banyak sekali perubahan pada pasar, baik pasar lokal maupun pasar secara global. Beberapa perubahan tersebut dapat kita amati secara langsung di pasar, seperti munculnya beberapa merek, pesaing baru, dan inovasi, prefensi konsumen yang bergeser, segmen pelanggan yang berkembang, informasi yang begitu cepat, serta pelanggan yang ingin perlakuan yang berbeda.

Consina sebagai salah satu merek yang menjual produk backpack yang saat ini mulai diminati oleh konsumen harus mampu bersaing dengan para kompetitornya. Consina sebagai merek outdoor yang baru muncul di Indonesia sejak tahun 1999 harus merebut hati konsumen backpack dari kompetitor yang telah lebih dahulu ada di pasar. Consina mengedepankan kualitas, desain dan daya tahan dari produk backpack yang di tawarkannya, sehingga banyak konsumen yang sudah mempercayai Consina sebagai backpack pilihan mereka. 
Namun pada gambar 2 terlihat bahwa merek Deuter masih merupakan merek yang paling dicari oleh masyarakat karena berada pada posisi pencarian paling tinggi, kemudian di bawahnya baru diikuti oleh merek Eiger yang merupakan merek lokal dari Indonesia. Di posisi ketiga saat ini ditempati oleh merek Consina yang sebelumnya pada tahun 2011 hingga 2014 berada di bawah merek Avtech. Hal ini menujukan bahwa preferensi konsumen terhadap merek Deuter dan Eiger masih lebih tinggi dibandingkan merek Consina, Avtech dan Cozmeed.

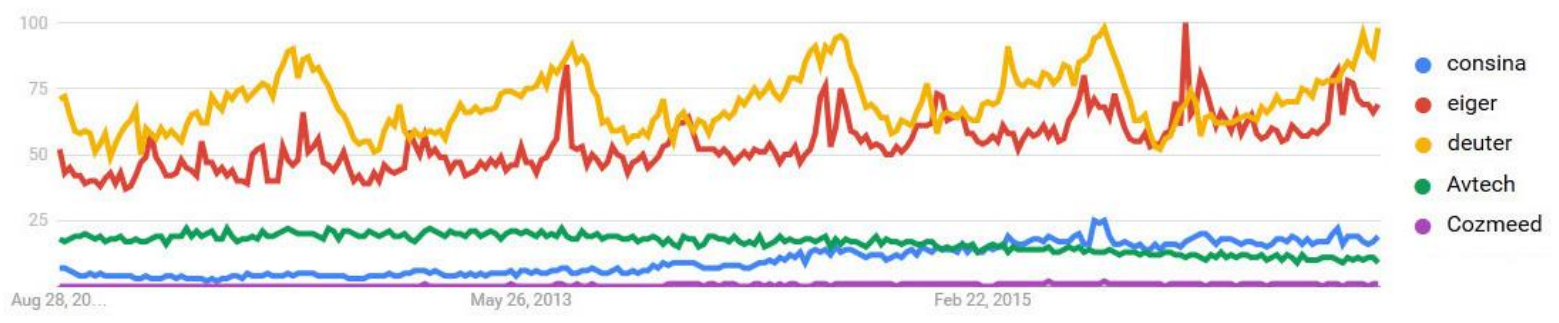

Gambar 2. Trend Merek Consina, Eiger, Deuter, Avtech dan Cozmeed 20112016

Sumber : Google Trends (www.google.com/trends/)

Dari gambar di atas kita dapat melihat Consina terus mengalami peningkatan melalui pencarian yang dilakukan oleh masyarakat. Namun peningkatan tersebut masih jauh dibandingkan dua kompetitor yang berada diatasnya, yaitu Deuter dan Eiger. Hal ini mungkin saja di pengaruhi karena konsumen masih mempersepsikan kualitas merek Consina masih lebih rendah dibandingkan dengan pesaingnya sehingga konsumen lebih tertarik dengan merek lain.

Dalam memilih produk backpack konsumen akan cenderung memilih merek backpack yang sudah mereka kenal dengan baik dan memberikan nilai lebih kepada dirinya, baik nilai secara fungsional maupun secara emosional. Hal tersebut akan mempengaruhi niat beli konsumen dalam menentukan backpack yang akan mereka beli. Sehingga Consina harus mampu menciptakan citra merek yang baik dan ikatan emosional yang kuat pada konsumennya.

Berdasarkan uraian yang telah dijelaskan diatas, penelitian ini dilakukan untuk menganalisis variabel persepsi kualitas, citra merek dan nilai emosional terhadap niat beli tas ransel Consina. 


\section{Rumusan Masalah}

Perumusan masalah merupakan hal yang paling penting dalam suatu penelitian, hal ini diperlukan agar batasan masalah menjadi jelas sehingga dapat dijadikan pedoman dalam melakukan penelitian. Adapun perumusan masalah pada penelitian ini adalah :

1. Bagaimana deskripsi persepsi kualitas (perceived quality), citra merek (brand image), nilai emosional (emotional value), dan niat beli (purchase intention) produk backpack Consina di Jakarta Timur?

2. Apakah persepsi kualitas (perceived quality) berpengaruh terhadap niat beli (purchase intention) produk backpack Consina?

3. Apakah citra merek (brand image) berpengaruh terhadap niat beli (purchase intention) produk backpack Consina?

4. Apakah nilai emosional (emotional value) berpengaruh terhadap niat beli (purchase intention) produk backpack Consina?

5. Apakah persepsi kualitas (perceived quality), citra merek (brand image) dan nilai emosional (emotional value) berpengaruh secara bersama-sama terhadap niat beli (purchase intention) produk backpack Consina?

\section{KAJIAN TEORITIK}

\section{Niat Beli}

Menurut Kotler dan Armstrong (2014) niat beli adalah bentuk setelah konsumen melakukan peringkatan pada merek dan ia akan membeli merek yang paling disukai. Konsumen mungkin membentuk niat beli berdasarkan faktorfaktor seperti pendapatan yang diharapkan, harga yang diharapkan, dan manfaat produk yang diharapkan.

Menurut Hawkins dan Mothersbaugh (2013) model proses keputusan pembelian terjadi dalam lima tahap, yaitu:

1. Problem recognition (pengenalan masalah)

2. Information search (pencarian informasi)

3. Alternative evaluation and selection (evaluasi alternatif dan pemilihan) 
4. Outlet selection and purchase (pemilihan gerai dan pembelian)

5. Postpurchase processes (proses pasca pembelian)

\section{Persepsi Kualitas}

Menurut Sadat (2009) persepsi kualitas adalah "menggambarkan respon kesuluruhan pelanggan terhadap kualitas dan keunggulan yang ditawarkan merek. Respon ini adalah persepsi yang terbentuk dari pengalaman pelanggan selama berinteraksi dengan merek melalui komunikasi yang dibangun oleh pemasar. Tentu saja kondisi seperti ini harus terus dijaga melalui pengembangan kualitas secara berkesinambungan.

Komponen penyusun perceived quality menurut Keller (2008) terdiri atas tujuh dimensi, yaitu :

1. Performance; tingkat karakteristik utama dari sebuah produk beroperasi (rendah, menengah, tinggi atau sangat tinggi)

2. Features; elemen sekunder dari sebuah produk yang melengkapi karakteristik utama

3. Conformance quality; sejauh mana sebuah produk memenuhi spesifikasi dan bebas dari cacat

4. Reliability; konsistensi dari performa produk dari masa ke masa

5. Durability; ekspetasi nilai hidup ekonomi dari sebuah produk

6. Serviceability; kemudahan dalam memperbaiki produk

7. Style and design; penampilan luar atau perasaan dari sebuah kualitas

\section{Citra Merek}

Menurut Hawkins dan Mothersbaugh (2013) citra merek (brand image) adalah mengacu pada memori skematik dari sebuah merek. Ini mengandung interpretasi target pasar terhadap atribut produk, manfaat, situasi penggunaan, pengguna, dan karakteristik pembuatan/pasar. Ini adalah apa yang orang pikirkan dan rasakan ketika mereka mendengar atau melihat nama merek. Itu adalah esensi, himpunan asosiasi yang telah konsumen pelajari tentang suatu merek. 
Menurut Cateora, Gilly, dan Graham (2009) citra merek (brand image) terbentuk atas beberapa dimensi jangka panjang selama beberapa tahun sejak brand tersebut ada, dimensi tersebut yaitu:

1. Advertising

2. Goodwill

3. Quality evaluations

4. Product experience

\section{Nilai Emosional}

Menurut Sadat (2009) nilai emosional adalah sentuhan emosional terhadap merek yang mereka tawarkan, meskipun untuk produk yang selama ini dipasarkan sebatas mengandalkan fungsinya. Melalui sentuhan emosional, para pemasar percaya bahwa hal yang ditawarkan akan memberikan perasaan tersendiri bagi pelanggannya.

Menurut Hawkins dan Mothersbaugh (2013) dimensi dari emotional value dan indikator yang membentuknya yaitu:

1. Pride: proud, superior, worthy

2. Affection: loving, affectionate, friendly

3. Serenity: restful, serene, comfortable, soothed

4. Desire: desirous, wishful, craving, hopeful

5. Joy: joyful, happy, delighted, pleased

6. Competene: confident, in control, competent 


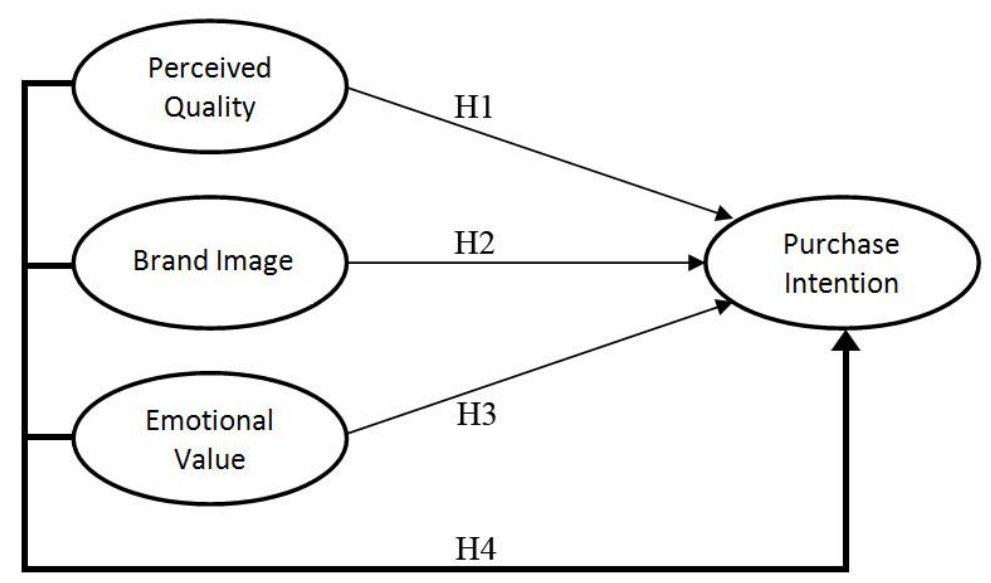

\section{Gambar 3. Model Penelitian}

Sumber : Data diolah peneliti

H1 : Persepsi kualitas berpengaruh terhadap niat beli

H2 : Citra merek berpengaruh terhadap niat beli

H3 : Nilai emosional berpengaruh terhadap niat beli

H4 : Persepsi kualitas, citra merek dan nilai emosional berpengaruh secara bersama-sama terhadap niat beli

\section{METODE PENELITIAN}

\section{Populasi dan Sampel}

Malhotra (2010) mengemukakan bahwa populasi ialah jumlah keseluruhan dari semua elemen yang memiliki kesamaan karakteristik serta meliputi keseluruhan obyek atau subjek untuk tujuan masalah dalam penelitian pemasaran. Populasi pada penelitian ini mengacu pada konsumen pengguna backpack di Jakarta Timur. Jenis populasi yang akan diteliti adalah populasi infinite, yaitu objek dengan ukuran yang tidak terhingga (infinite), yang karakteristiknya dikaji atau diuji melalui sampling karena peneliti tidak mengetahui jumlah pengguna backpack di Jakarta Timur.

Malhotra (2010) mengungkapkan bahwa sampel adalah sebuah subgroup dari sebuah elemen populasi terpilih untuk berpartisipasi dalam sebuah studi. Sampel yang Menurut Malhotra sampel ialah subkelompok elemen dari populasi yang dipilih untuk berpartisipasi di dalam sebuah penelitian akan digunakan dalam 
penelitian ini berjumlah 200. Metode sampling yang digunakan dalam penelitian ini adalah purposivesampling. Menurut Sekaran dan Bougie (2010), purposivesampling adalah peneliti memperoleh informasi dari mereka yang paling siap dan memenuhi beberapa kriteria yang dibutuhkan dalam memberikan informasi. Dalam penelitian ini responden yang memenuhi kriteria adalah konsumen backpack yang berdomisili di Jakarta Timur serta mengetahui produk backpack bermerek Consina.

\section{Pengumpulan Data}

Pengumpulan data ini dilakukan melalui pembagian kuesioner kepada responden. Penelitian ini menggunakan skala likert sebagai alat penelitian untuk mengukur pernyataan yang tercantum pada kuisioner. Skala likert yang digunakan dalam penelitian ini menggunakan 5 kategori respons berkisar dari "sangat tidak setuju" sampai "sangat setuju," dimana responden dibutuhkan untuk mengindikasikan sebuah tingkat ketidaksetujuan atau kesetujuan dengan masingmasing seri pernyataan terhubung dengan objek stimulus. Nilai-nilai yang diberikan dari tiap skala adalah:

$\begin{array}{ll}\text { Sangat Tidak Setuju } & \text { Memiliki nilai 1 } \\ \text { Tidak Setuju } & \text { Memiliki nilai 2 } \\ \text { Biasa Saja } & \text { Memiliki nilai 3 } \\ \text { Setuju } & \text { Memiliki nilai 4 } \\ \text { Sangat Setuju } & \text { Memiliki nilai 5 }\end{array}$

\section{METODE PENELITIAN}

Tujuan metode analisis data adalah untuk menginterprestasikan dan menarik kesimpulan dari sejumlah data yang terkumpul. Peneliti menggunakan perangkat lunak atau program SPSS for Windows 20 untuk mengolah dan menganalisis data hasil penelitian. 


\section{HASIL DAN PEMBAHASAN}

\section{Hasil Uji Instrumen}

\section{Uji Validitas}

Validitas menurut Sekaran dan Bougie (2010) ialah ketepatan atau kecermatan suatu instrumen dalam mengukur konsep tertentu. Uji validitas digunakan untuk mengukur sah atau valid tidaknya suatu kuisioner. Uji validitas dalam penelitian ini dilakukan kepada 50 orang responden yang berdomisili di area Jakarta Timur serta mengetahui backpack bermerek Consina. Perhitungan uji validitas dilakukan dengan menggunakan korelasi bivariate pearson (product moment) yang diolah menggunakan software IBM Statistical Product and Service Solution (SPSS) versi 20. Jika $r_{\text {hitung }}>r_{\text {tabel }}(0,279)$, maka instrumen atau item pernyataan berkorelasi signifikan terhadap skor total (dinyatakan valid).

\section{Tabel 1. Hasil Uji Validitas Variabel Persepsi Kualitas}

\begin{tabular}{llll}
$\begin{array}{l}\text { No. Item } \\
\text { pernyataan }\end{array}$ & $\mathbf{r}_{\text {hitung }}$ & $\mathbf{r}_{\text {tabel }}$ & Keterangan \\
\hline $\mathbf{1}$ & 0.733 & 0.279 & valid \\
\hline $\mathbf{2}$ & 0.679 & 0.279 & valid \\
\hline $\mathbf{3}$ & 0.789 & 0.279 & valid \\
\hline $\mathbf{4}$ & 0.486 & 0.279 & valid \\
\hline $\mathbf{5}$ & 0.840 & 0.279 & valid \\
\hline $\mathbf{6}$ & 0.783 & 0.279 & valid \\
\hline $\mathbf{7}$ & 0.825 & 0.279 & valid
\end{tabular}

Sumber: Data diolah peneliti

\section{Tabel 2. Hasil Uji Validitas Variabel Citra Merek}

\begin{tabular}{llll}
$\begin{array}{l}\text { No. Item } \\
\text { pernyataan }\end{array}$ & $\mathbf{r}_{\text {hitung }}$ & $\mathbf{r}_{\text {tabel }}$ & Keterangan \\
\hline $\mathbf{1}$ & 0.692 & 0.279 & valid \\
\hline $\mathbf{2}$ & 0.642 & 0.279 & valid \\
\hline $\mathbf{3}$ & 0.692 & 0.279 & valid \\
\hline $\mathbf{4}$ & 0.621 & 0.279 & valid \\
\hline $\mathbf{5}$ & 0.771 & 0.279 & valid \\
\hline $\mathbf{6}$ & 0.556 & 0.279 & valid \\
\hline $\mathbf{7}$ & 0.632 & 0.279 & valid
\end{tabular}

Sumber: Data diolah peneliti 
Tabel 3. Hasil Uji Validitas Variabel Nilai Emosional

\begin{tabular}{llll}
$\begin{array}{l}\text { No. Item } \\
\text { pernyataan }\end{array}$ & $\mathbf{r}_{\text {hitung }}$ & $\mathbf{r}_{\text {tabel }}$ & Keterangan \\
\hline $\mathbf{1}$ & 0.744 & 0.279 & valid \\
\hline $\mathbf{2}$ & 0.856 & 0.279 & valid \\
\hline $\mathbf{3}$ & 0.847 & 0.279 & valid \\
\hline $\mathbf{4}$ & 0.755 & 0.279 & valid \\
\hline $\mathbf{5}$ & 0.804 & 0.279 & valid \\
\hline $\mathbf{6}$ & 0.780 & 0.279 & valid
\end{tabular}

Sumber: Data diolah peneliti

Tabel 4. Hasil Uji Validitas Variabel Niat Beli

\begin{tabular}{llll}
$\begin{array}{l}\text { No. Item } \\
\text { pernyataan }\end{array}$ & $\mathbf{r}_{\text {hitung }}$ & $\mathbf{r}_{\text {tabel }}$ & Keterangan \\
\hline $\mathbf{1}$ & 0.616 & 0.279 & valid \\
\hline $\mathbf{2}$ & 0.468 & 0.279 & valid \\
\hline $\mathbf{3}$ & 0.637 & 0.279 & valid \\
\hline $\mathbf{4}$ & 0.541 & 0.279 & valid \\
\hline $\mathbf{5}$ & 0.863 & 0.279 & valid \\
\hline $\mathbf{6}$ & 0.719 & 0.279 & valid \\
\hline $\mathbf{7}$ & 0.733 & 0.279 & valid \\
\hline $\mathbf{8}$ & 0.777 & 0.279 & valid
\end{tabular}

Sumber: Data diolah peneliti

\section{Uji Reliabilitas}

Suatu kuisioner dikatakan reliabel atau handal jika jawaban seseorang terhadap pertanyaan adalah konsisten atau stabil dari waktu ke waktu. Untuk pengujian biasanya menggunakan batasan tertentu seperti 0,6. Jika reliabilitas kurang dari 0,6 adalah kurang baik, sedangkan 0,7 adalah cukup baik, dan 0,8 adalah baik. Berikut ini adalah hasil uji reliabilitas dari masing-masing variabel:

\section{Tabel 5. Hasil Uji Reliabilitas}

\begin{tabular}{llll} 
No & Variabel & $\begin{array}{l}\text { Nilai Cronbach's } \\
\text { Alpha }(\boldsymbol{\alpha})\end{array}$ & Keterangan \\
\hline $\mathbf{1}$ & Persepsi Kualitas (X1) & 0.854 & reliabel \\
\hline $\mathbf{2}$ & Citra Merek (X2) & 0.771 & reliabel \\
\hline $\mathbf{3}$ & Nilai Emosional (X3) & 0.881 & reliabel \\
\hline $\mathbf{4}$ & Niat Beli (Y) & 0.819 & reliabel
\end{tabular}

Sumber: Data diolah peneliti 


\section{Hasil Uji Asumsi Klasik}

\section{Uji Normalitas}

Dalam penelitian ini untuk menguji nilai residual digunakan uji One Sample Kolmogorov-Smirnov dengan mengkorelasikan nilai residual (Unstandarized residual) dari masing-masing variabel yang menggunakan nilai signifikan 0,05.

Tabel 6. Hasil Uji Normalitas

\begin{tabular}{llll} 
No & Variabel & Nilai Signifikansi & Keterangan \\
\hline $\mathbf{1}$ & Persepsi Kualitas (X1) & 0.128 & normal \\
\hline $\mathbf{2}$ & Citra Merek (X2) & 0.086 & normal \\
\hline $\mathbf{3}$ & Nilai Emosional (X3) & 0.061 & normal \\
\hline $\mathbf{4}$ & Niat Beli (Y) & 0.087 & normal
\end{tabular}

Sumber: Data diolah peneliti

Tabel 7. Hasil Uji Normalitas Residual

\begin{tabular}{llll} 
No & Variabel & Nilai Signifikansi & Keterangan \\
\hline $\mathbf{1}$ & Persepsi Kualitas (X1) & 0.847 & normal \\
\hline $\mathbf{2}$ & Citra Merek (X2) & 0.352 & normal \\
\hline $\mathbf{3}$ & Nilai Emosional (X3) & 0.317 & normal \\
\hline $\mathbf{4}$ & Niat Beli (Y) & 0.087 & normal
\end{tabular}

Sumber: Data diolah peneliti

Model regresi yang baik adalah model yang memiliki nilai residualnya terdistribusi normal. Pada Tabel 7, berdasarkan uji normalitas residual yang dilakukan pada ketiga model residual, unstandardized residual 1 yang mempengaruhi persepsi kualitas (X1) dengan niat beli (Y), unstandardized residual 2 yang mempengaruhi citra merek (X2) dengan niat beli (Y), dan unstandardized residual 3 yang mempengaruhi nilai emosional (X3) terhadap niat beli (Y), ketiganya memiliki nilai signifikansi melebihi dari $\alpha=0,05$, maka dapat dikatakan nilai ketiga model residual berdistribusi normal.

\section{Uji Linearitas}

Uji linearitas biasanya digunakan sebagai prasyarat dalam analisis korelasi atau regresi linear. Pengujian dapat dilakukan pada taraf signifikasi 0,05.

\section{Tabel 8. Hasil Uji Linearitas}

\begin{tabular}{llll} 
No & Variabel & Nilai Signifikansi & Keterangan \\
\hline $\mathbf{1}$ & Persepsi Kualitas (X1) & 0.000 & linear \\
\hline
\end{tabular}




\begin{tabular}{llll}
\hline $\mathbf{2}$ & Citra Merek (X2) & 0.000 & linear \\
\hline $\mathbf{3}$ & Nilai Emosional (X3) & 0.000 & linear
\end{tabular}

Sumber: Data diolah peneliti

Pada tabel 8 dapat terlihat bahwa ada hubungan yang linear antara variabel bebas terhadap varuabel terikat, karena memiliki nilai signifikansi sebesar 0,000 , 0,000 dan 0,000 dimana nilai tersebut $<$ dari 0,05.

\section{Uji Multikolinearitas}

Dalam penelitian ini uji multikolinearitas dilakukan dengan melihat value inflation factor (VIF) pada model regresi. Jika VIF >5, maka variabel tersebut mempunyai persoalan multikolinearitas dengan variabel bebas lainnya.

\section{Tabel 9. Hasil Uji Multikolinearitas}

\begin{tabular}{llll} 
No & Variabel & Tolerance & VIF \\
\hline $\mathbf{1}$ & Persepsi Kualitas (X1) & 0.463 & 2.161 \\
\hline $\mathbf{2}$ & Citra Merek (X2) & 0.463 & 2.158 \\
\hline $\mathbf{3}$ & Nilai Emosional (X3) & 0.430 & 2.326
\end{tabular}

Sumber: Data diolah peneliti

Pada tabel 9 dapat terlihat bahwa tidak ada hubungan antara variabel bebas, karena memiliki nilai VIF sebesar 2,161, 2,158 dan 2,326 dimana nilai tersebut < dari 5 .

\section{Uji Heteroskedastisitas}

Dalam penelitian ini, uji heteroskedastisitas dilakukan dengan menggunakan uji Glejser, yaitu dengan cara meregresikan variabel bebas terhadap nilai absolute residualnya. Kriteria agar bebas dari heteroskedastisitas ialah apabila nilai signifikansi lebih dari 0,05 (sig > 0,05)

\section{Tabel 10. Hasil Uji Heteroskedastisitas}

\begin{tabular}{lll} 
No & Variabel & Nilai Signifikansi \\
\hline $\mathbf{1}$ & Persepsi Kualitas (X1) & 0.669 \\
\hline $\mathbf{2}$ & Citra Merek (X2) & 0.994 \\
\hline $\mathbf{3}$ & Nilai Emosional (X3) & 0.942
\end{tabular}

Sumber: Data diolah peneliti 
Pada tabel 10 dapat terlihat bahwa tidak ada gejala heteroskedastisitas, karena memiliki nilai signifikan sebesar 0,669, 0,994 dan 0,942 dimana nilai tersebut > dari 0,05 .

\section{Hasil Uji Regresi Berganda}

\section{Uji Regresi Parsial (Uji t)}

Suatu hipotesis dapat dikatakan memiliki pengaruh apabila memenuhi syarat dalam regresi berganda, apabila memiliki nilai signifikan $\leq 0,05$ dan syarat $t_{\text {hitung }}>$ $\mathrm{t}_{\text {tabel, }}$, maka $\mathrm{H} 1, \mathrm{H} 2$ dan $\mathrm{H} 3$ diterima. Berikut adalah hasil uji analisis regresi berganda pada penelitian ini, sebagai berikut :

Tabel 11. Hasil Uji t

\begin{tabular}{llll} 
No & Variabel & $\mathbf{t}_{\text {hitung }}$ & $\begin{array}{l}\text { nilai } \\
\text { signifikansi }\end{array}$ \\
\hline $\mathbf{1}$ & Persepsi Kualitas (X1) & 3.450 & 0.001 \\
\hline $\mathbf{2}$ & Citra Merek (X2) & 3.115 & 0.002 \\
\hline $\mathbf{3}$ & Nilai Emosional (X3) & 8.120 & 0.000
\end{tabular}

Sumber: Data diolah peneliti

Berdasarkan Tabel 11 diketahui bahwa nilai $t_{\text {hitung variabel persepsi kualitas }}$ (X1) adalah sebesar 3,450, variabel citra merek (X2) adalah sebesar 3,115, dan variabel nilai emosional (X3) adalah sebesar 8,120. Nilai signifikansi variabel persepsi kualitas (X1) adalah sebesar 0,001, variabel citra merek (X2) adalah sebesar 0,002 dan variabel nilai emosional (X3) adalah sebesar 0,000. Dengan demikian $t_{\text {hitung }}$ ketiga variabel 3,450, 3,115 dan 8,120 > $t_{\text {tabel }}(1,972)$ serta nilai signifikansi ketiga variabel 0,001, 0,002 dan 0,000 $<0.05$. Berdasarkan hasil tersebut, maka artinya ada pengaruh secara parsial antara variabel persepsi kualitas terhadap variabel niat beli, variabel citra merek terhadap niat beli, dan variabel nilai emosional terhadap niat beli.

\section{Uji Regresi Simultan (Uji F)}

Suatu hipotesis dapat dikatakan memiliki hubungan secara bersama-sama apabila memenuhi syarat, dengan tingkat kepercayaan sebesar 0,05 atau $\alpha=0,05$ maka dapat ditentukan dengan melihat nilai signifikansi, dimana nilai signifikan < 0,05 dan syarat $F_{\text {hitung }}>F_{\text {tabel}}$, maka $\mathrm{H} 4$ diterima. 
Tabel 12. Hasil Uji F

\begin{tabular}{|c|c|c|c|c|c|c|}
\hline \multicolumn{7}{|c|}{ ANOVA $^{\mathbf{a}}$} \\
\hline Model & & Sum & of $\mathrm{df}$ & Mean & $\mathrm{F}$ & Sig. \\
\hline \multirow{3}{*}{1} & Regression & 2268,494 & 3 & 756,165 & 131,570 &, $000^{b}$ \\
\hline & Residual & 1126,461 & 196 & 5,747 & & \\
\hline & Total & 3394,955 & 199 & & & \\
\hline
\end{tabular}

Sumber: Data diolah peneliti

Pada tabel 12 dapat terlihat bahwa berdasarkan perhitungan tersebut maka $F_{\text {hitung }}(131,570)>F_{\text {tabel }}(2,650)$ dan nilai signifikansi lebih kecil dari 0,05 atau mempunyai nilai signifikansi 0,000, atau dengan kata lain, terdapat hubungan yang signifikan secara bersama-sama antara persepsi (X1), citra merek (X2) dan nilai emosional (X3) dengan niat beli (Y).

\section{Koefisien Determinasi}

Koefisien determinasi ini menunjukan seberapa besar persentase variasi variabel independen yang digunakan dalam model mampu menjelaskan variasi variabel dependen.

\section{Tabel 13. Hasil Koefisien Determinasi}

\begin{tabular}{lllll} 
Model & R & R Square & $\begin{array}{l}\text { Adjusted } \\
\text { Square }\end{array}$ & $\begin{array}{c}\text { R Std. Error of } \\
\text { the Estimate }\end{array}$ \\
\hline 1 &, $817^{\mathrm{a}}$ &, 668 & $\mathbf{, 6 6 3}$ & 2,397
\end{tabular}

Sumber: Data diolah peneliti

Dari tabel di atas, dapat dilihat bahwa nilai $\mathrm{R}^{2}$ (Adjusted $R$ square) sebesar 0,663 atau 66,3\%. Angka ini menjelaskan bahwa variasi variabel independen yang digunakan dalam model, yaitu persepsi kualitas (X1), citra merek (X2) dan nilai emosional (X3) mampu menjelaskan sebesar 66,3\% variasi pada variabel dependen, yaitu niat beli. Sedangkan sisanya 33,7\% dipengaruhi atau dijelaskan oleh variabel lain yang tidak dimasukkan dalam model penelitian ini. 


\section{KESIMPULAN DAN SARAN}

\section{Kesimpulan}

1. Hipotesis pertama menyatakan bahwa persepsi kualitas berpengaruh terhadap niat beli diterima karena memiliki nilai $\mathrm{t}$ hitung 3,450>t tabel 1,972 dengan nilai signifikansi $0,001<5 \%(\alpha=0,05)$. Selanjutnya Persepsi kualitas memiliki pengaruh positif terhadap niat beli karena memiliki nilai koefisien regresi sebesar 0,273.

2. Hipotesis kedua menyatakan bahwa citra merek berpengaruh terhadap niat beli diterima karena memiliki nilai $\mathrm{t}_{\text {hitung }} 3,115>\mathrm{t}_{\text {tabel }}$ 1,972 dengan nilai signifikansi $0,002<5 \%(\alpha=0,05)$. Selanjutnya Citra merek memiliki pengaruh positif terhadap niat beli karena memiliki nilai koefisien regresi sebesar 0,252 .

3. Hipotesis ketiga menyatakan bahwa nilai emosional berpengaruh terhadap niat beli diterima karena memiliki nilai $\mathrm{t}_{\text {hitung }} 8,120>\mathrm{t}$ tabel 1,972 dengan nilai signifikansi $0,000<5 \%(\alpha=0,05)$. Selanjutnya nilai emosional memiliki pengaruh positif terhadap niat beli karena memiliki nilai koefisien regresi sebesar 0,701 .

4. Hipotesis keempat menyatakan bahwa persepsi kualitas, citra merek dan nilai emosional berpengaruh secara bersama-sama terhadap niat beli diterima karena memiliki nilai $\mathrm{f}_{\text {hitung }} 131,570>\mathrm{f}_{\text {tabel }} 2,650$ dengan nilai signifikansi $0,000<5 \%(\alpha=0,05)$.

\section{Saran}

a. Pihak perusahaan CV Consina Segar Alam sebaiknya menambahkan variasi desain produk backpacknya. Desain yang baik bukan hanya desain yang memiliki tampilan luar yang bagus dan memanjakan mata, namun desain juga harus memberikan kenyamanan saat produk tersebut digunakan.

b. Pihak perusahaan CV Consina Segar Alam harus meningkatkan perhatiannya pada konsumen, seperti melayani setiap pertanyaan dan 
keluhan konsumen mengenai produk-produk Consina baik melalui layanan call center ataupun melalui akun-akun media sosial milik Consina.

c. Pihak perusahaan CV Consina Segar Alam hendaknya memperluas pasar dengan memperbanyak outlet-outlet resmi dan memperluas distribution channel di berbagai kota, terutama kota-kota yang sering menjadi destinasi wisata outdoor.

d. Pihak perusahaan CV Consina Segar Alam sebaiknya memperbanyak membuat event yang menarik bagi kalangan pecinta kegiatan outdoor. Seperti kegiatan wall climbing, hiking, pendakian bersama, outdoor run, fun trail dan mendayung yang terbuka untuk masyarakat umum.

e. Pihak perusahaan CV Consina Segar Alam sebaiknya memiliki brand ambassador. Dengan memiliki brand ambassdor, Consina dapat meningkatkan nilai dari merek Consina itu sendiri.

\section{DAFTAR PUSTAKA}

Ahmed, Shehrin. 2014. Bangladeshi Consumers' Purchase Intention toward Global Brands over Local Brands. IISTE ISSN 2224-607X (Paper) ISSN 2225-0565 (Online) Vol.4, No.26

Antyadika, Bonaventura Efrian. 2012. Analisis Pengaruh Lokasi, Harga, Dan Kualitas Produk Terhadap Keputusan Pembelian (Studi pada Wong Art Bakery \& Café Semarang). Universitas Diponegoro. Skripsi.

Asshiddieqi dan Mudiantono. 2012. Analisis Pengaruh Harga, Desain Produk dan Citra Merek terhadap Keputusan Pembelian (Studi Kasus pada Produk Crooz di Distro Ultraa Store Semarang). Diponegoro Journal of Management, Vol 1, No 1

Cahyadi, Imam Febri. 2014. Pengaruh Persepsi Harga, Atribut Produk dan Persepsi Risiko Terhadap Keputusan Pembelian Susu Formula (Studi pada konsumen susu formula SGM di Kota Yogyakarta). Universitas Negeri Yogyakarta. Skripsi.

Cateora, Gilly, dan Graham. 2009. International Marketing 14e. New York: McGraw-Hill Companies, Inc. 
Clow dan Baack. 2014. Integrated Advertising, Promotion, and Marketing Communications 6e. USA: Pearson Education Limited

Faraditta dan Mudiantono. 2015. Analisis Pengaruh Country of Origin Perception, Perceived Quality dan Consumer Perception terhadap Purchase Intention dengan Brand Image sebagai Variabel Intervening. ISSN 2302 - 9791. Vol. 2 No. 1

Ferdinand, Augusty. 2006. Metode Penelitian Manajemen : Pedoman Penelitian untuk Penulisan Skripsi, Tesis, dan Disertasi Ilmu Manajemen. Semarang: Badan Penerbit Universitas Diponegoro

Gozhali, Imam. 2012. Aplikasi Analisis Multivariate dengan Program IBM SPSS 20. Semarang: Badan Penerbit Universitas Diponegoro

Hawkins dan Mothersbaugh. 2013. Consumer Behavior: Building Marketing Strategy 12e. New York: McGraw-Hill Companies, Inc.

Kapferer, Jean-Noel. 2012. The New Strategic Brand Management : Advanced insights and strategic thinking 5e. London: Les Editions d'Organization

Keegan dan Green. 2013. Global Marketing 7e. USA: Pearson Education Ltd.

Keller, Kevin Lane. 2008. Strategic Brand Management : Building, Measuring, and Managing Brand Equity 3e. USA: Pearson Prentice Hal

Kotler, Philip dan Keller, Kevin. 2015. Marketing Management. $15^{e}$ Global Edition. New Jersey: Pearson Education Ltd.

Kotler dan Armstrong. 2014. Principles of Marketing 15e. USA: Pearson Education, Inc.

Kurtz, David L. 2015. Contemporary Marketing. USA: Cengage Learning

Malhotra, Naresh K. 2010. Marketing Research An Applied Orientation 6e. New Jearsey: Pearson

Marieke de Mooij. 2005. Global Marketing and Advertising: Understanding Cultural Paradoxes 2e. USA: Sage Publications, Inc.

Peter dan Olson. 2010. Consumer Behavior \& Marketing Strategy 9e. Singapore: McGraw-Hill Education Asia

Poh K. Tee, Behrooz Gharleghi, Benjamin Chan, Behrang Samadi dan Abbas A. Balahmar. 2015. Purchase Intention of International Branded Clothes 
Fashion among Younger's in Jakarta. International Journal of Business and Social Research, Vol 05, Issue 08

Pratisto Arif. 2004. Cara Mudah Mengatasi Masalah Statistik dan Rancangan Percobaan dengan SPSS. Jakarta: PT. Elex Media Komputindo

Priyatno, Duwi. 2010. Teknik Mudah dan Cepat Melakukan Analisis Data Penelitian dengan SPSS dan Tanya Jawab Ujian Pendadaran. Yogyakarta: Gaya Media

Priyatno, Duwi. 2010. Paham Analisa Statistik Data dengan SPSS. Yogyakarta: MediaKom

Puspitarini, Dian. 2013. Pengaruh Faktor Kebudayaan, Sosial, Pribadi, dan Psikologi Terhadap Proses Keputusan Pembelian Produk Pizza (Studi Pada Pizza Hut Cabang Jalan Jendral Sudirman No. 53 Yogyakarta). Universitas Negeri Yogyakarta. Skripsi.

Sadat, Andi M. 2009. Brand Belief : Strategi Membangun Merek Berbasis Keyakinan. Jakarta: Salemba Empat

Saeednia dan Ghorbanzade. 2014. Factors Influencing Islamic Azad University Students Purchase Intention toward Foreign Apparel Brands. Academic Journal of Research in Business and Accounting Vol. 2, No. 10, December 2014, 63-73, ISSN: 2311-326X

Safarnia dan Mollahosseini. 2013. Iranian Consumers' Purchase Intention toward Global Brands. Interdisciplinary Journal of Contemporary Research in Business Vol 5, No 8

Sarjono dan Julianita. 2011. SPSS vs LISREL, Sebuah Pengantar Aplikasi Untuk Riset. Jakarta : Salemba Empat

Sarmad, Imran. 2015. Factor Affecting Consumer Purchase Intention toward Multinational Apparel Brands. Journal of Basic and Applied Scientific Research ISSN 2090-4304

Shah I. Shah, Shahzad Akmal, Ahmed Tanvir dan Ahmed Irfan. 2012. Factor Affecting Pakistan's University Students' Purchase Intention Toward Foreign Apparel Brands. Journal of Management Vol. 17 
Uma Sekaran dan Roger Bougie. 2013. Research Methods for Business. United Kingdom: John Wiley and Sons Ltd.

Umboh O. Sisilia, Tumbel Altje dan Soepeno Djurwati. 2015. Analisa Kualitas Produk, Brand Image dan Life Style terhadap Keputusan Pembelian Pakaian Wanita di Mississippi Mando Town Square" Jurnal EMBA Vol.3 No.1 Maret 2015, Hal. 1096-1105, ISSN 2303-1174

Vikkraman dan Sumathi. Purchase Behaviour in Indian Apparel Market: an Analysis. ZENITH International Journal of Business Economics \& Management Research, Vol.2 Issue 2, ISSN 2249 8826, February 2012.

Deuter. Our History. http://www.deuter.com/DE/en/about-deuter.html (Diakses pada tanggal 21 Januari 2017)

Google trends. Trend Consina, Eiger, Deuter, Avtech, Cozmeed 2011-2016. www.google.com/trends/ (Diakses pada tanggal 28 Agustus 2016)

Sciencedirect. Perjuangan Dyson Merangsek Pasar Outdoor. http://www.sciencedirect.com/science/article/pii/S0148296308001665 (Diakses pada tanggal 28 Maret 2016)

Swa. Ini Resep Eiger Kuasai Pasar. http://swa.co.id/swa/trends/marketing/iniresep-eiger-kuasai-pasar (Diakses pada tanggal 21 Januari 2017. 